\title{
Ex situ conservation of two threatened ferns of the Western Ghats through in vitro spore culture
}

\author{
Johnson Marimuthu ${ }^{1} \&$ Visuvasam Soosai Manickam ${ }^{2}$ \\ ${ }^{1}$ Department of Plant Biology and Biotechnology, ${ }^{2}$ Centre for Biodiversity and Biotechnology, \\ St. Xavier's college (Autonomous), Palayamkottai, Tamil Nadu 627002, India \\ Email: ${ }^{1}$ ptcjohnson@gmail.com (corresponding author), ${ }^{2}$ vsmanickam@gmail.com
}

Date of publication (online): 26 July 2011 Date of publication (print): 26 July 2011 ISSN 0974-7907 (online) | 0974-7893 (print)

Editor: V. Irudayaraj

\section{Manuscript details:}

Ms \# 02687

Received 28 January 2011

Final received 08 June 2011

Finally accepted 27 June 2011

Citation: Marimuthu, J. \& V.S. Manickam (2011). Ex situ conservation of two threatened ferns of the Western Ghats through in vitro spore culture. Journal of Threatened Taxa 3(7): $1919-1928$

Copyright: $\odot$ Johnson Marimuthu \& Visuvassam Soosai Manickam 2011. Creative Commons Attribution 3.0 Unported License. JoTT allows unrestricted use of this article in any medium for non-profit purposes, reproduction and distribution by providing adequate credit to the authors and the source of publication.

Author Details: see end of this article

Author Contribution: JM executed the work and contributed for paper writing; VSM was the prinicpal investigator of the project and he only suggested the problem, given guidelines and contributed for paper writing.

Acknowledgements: The authors acknowledge the financial assistance from Ministry of Environment and Forests, Government of India, New Delhi, India.

Ministry of Environment and Forests GOVERNMENT OF INDIA
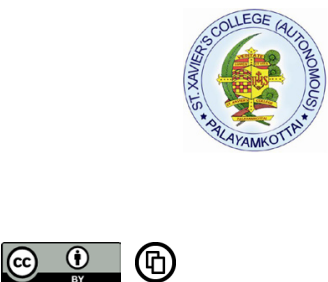

OPEN ACCESS | FREE DOWNLOAD

\begin{abstract}
The present study was intended to produce a protocol for the conservation of two endangered ferns of southern Western Ghats of India using in vitro spore culture. In addition this study reports spore germination, gametophyte development, changes in the reproductive phases and sporophytes formation of the medicinally important ferns Pronephrium triphyllum (Sw.) Holttum and Sphaerostephanos unitus (L.) (Holttum). Matured spores of the two selected ferns were harvested, filtered through $40 \mu \mathrm{M}$ nylon membrane and sterilized with $0.1 \%$ mercuric chloride for 3 to 5 min and rinsed with sterile distilled water for 15 min showed less frequency of mortality and a high percentage of spore germinations. For Pronephrium triphyllum, the spores sown on the Knop's basal agar medium showed the highest percentage (38.3 \pm 1.13$)$ of germination. Highest percentage $(52.3 \pm 1.43)$ of sporophyte formation was observed in Knop's liquid medium. For Sphaerostephanos unitus, the highest percentage $(36.8 \pm 1.31)$ of spore germination was observed in the Knop's basal agar. The highest percentage of sporophyte formation was observed only in Knop's medium (76.8 \pm 1.41$)$, other media failed to induce sporophyte formation. The in vitro raised plantlets were hardened and established in the natural habitat and distributed to various botanic gardens as a part of ex situ conservation. Cytological and isoperoxidase analysis confirmed the genetic uniformity between mother plants and in vitro raised sporophytes / plants. The established protocol of the present study will be useful for the multiplication and conservation of the two threatened ferns of the Western Ghats. The same protocol may also be applicable to similar threatened ferns.
\end{abstract}

Keywords: Conservation, ex situ, ferns, isoperoxidase, Pronephrium triphyllum, Sphaerostephanos unitus, spore.

\section{INTRODUCTION}

The Western Ghats is one of the hotspots of the world and also one of the significant geographical regions. Around 233 species of ferns occur in southern India (Manickam \& Irudayaraj 1992). In China, South Africa, USA, Europe and Canada, the ferns are used as medicines to cure diseases such as chest complaints, cancer, rheumatism, bowel disorder, ulcer, cough, fever and Alzheimer disease. In China alone, 401 kinds of pteridophytic medicines have been used for various ailments (Luo 1998). The economic value of the ferns has been enumerated by various authors from time to time (Kaur 1989). Today, the diversity of plant life is facing serious threats, largely due to habitat loss, habitat degradation and increasing exploitation of natural resources. It has been estimated that globally $30 \%$ of the flora is threatened (Raven 1999). The decline in the number and quality of the habitats is attributed to encroaching urbanization, growing industrialization, intensive farming and unsustainable harvesting of wild species. According to the World Resource Institute, India figures among 28 countries that are facing severe effects of increasing ecological imbalance if preservation is not taken on a war footing. The IUCN report says that in India $7.7 \%$ of the plants are under threat. In Western Ghats, a number 
of epiphytic and lithophytic ferns are destroyed due to various deforestation activities. In the Western Ghats, 44 threatened ferns are facing extinction and the conservation of these species is a major concern of biologists (Manickam 1995). The establishment of plantations of cash crops like cardamom, coffee, rubber and tea is the main reason for the destruction of the evergreen forests and consequent demise of the ferns in the Western Ghats. A reduction in the anthropogenic pressure on natural populations would contribute to their conservation in nature. Among the various biotechnological options, also reported in other agri-horticultural crops, micropropagation through tissue culture and in vitro spore germination are best applied and commercially exploited in fern species (Fay 1994). Application of this technology (in vitro spore germination) for large-scale multiplication of certain species of ferns from the Western Ghats has been demonstrated (Sara et al. 1998; Manickam et al. 2003; Johnson et al. 2005; Sara \& Manickam 2005; Johnson \& Manickam 2006; Sara \& Manickam 2007; Johnson \& Manickam 2007; Johnson et al. 2008). The plant tissue culture as an effective tool to conserve plant genes and guarantee the survival of the endemic, endangered and over exploited genotypes is derived from the fact that it makes use of small units (cells and tissues) without losing the mother plant, takes pressure off the waning wild populations and makes available large numbers of plants for reintroduction and commercial delivery. Endangered ferns such as Diplazium cognatum, Histiopteris incisa, Hypodematium crenatum, Thelypteris confluens, Athyrium nigripes, Pteris vittata, Metathelypteris flaccida, Pteris gongalensis, Pteris confusa, Cyathea crinita, Cheilanthes viridis, Pronephrium articulatum, and Nephrolepis multiflora have been multiplied through in vitro spore culture as a part of ex situ conservation (Sara 2001; Johnson 2003; Manickam et al. 2003; Irudayaraj et al. 2003; Vallinayagam 2003). Based on this background, the present investigation was initiated to extend the good work already done in our laboratory to a few other equally endangered species. In the present study in vitro spore culture has been attempted as part of our continued efforts to conserve species of conservation importance and prospective economic value. Reintroduction of the plants so multiplied through spore culture in selected forest habitats hitherto untested in our centre has also been attempted.

\section{MATERIALS AND METHODS}

Two rare and endangered ferns from the Western Ghats were selected for the present study viz., Pronephrium triphyllum (Sw.) Holttum (Thelypteridaceae) and Sphaerostephanos unitus (L.) (Holttum) (Theylpteridaceae). Matured fertile fronds of the selected species were collected from the wild of the Western Ghats and established in the green house attached to the Centre for Biodiversity and Biotechnology, St. Xavier's College, Palayamkottai, India. The fronds were washed in running tap water for a few minutes. The fronds were cut into small pieces and dried over white absorbent paper at room temperature $\left(25^{\circ} \mathrm{C}\right)$. After drying the fronds over the absorbent paper at room temperature for $24 \mathrm{hr}$, the liberated spores were passed through $40 \mathrm{~mm}$ nylon mesh to remove the sporangial wall materials and the clean spores were collected and stored in a refrigerator at $5^{\circ} \mathrm{C}$ (Images $1 \mathrm{a} \& 2 \mathrm{a}$ ). The spores were surface sterilized with $0.1 \% \mathrm{HgCl}_{2}$ solution for $5 \mathrm{~min}$ and washed with sterile distilled water for $15 \mathrm{~min}$. The surface sterilized spores were inoculated onto different media viz., Knops (1906), Knudson (1946), Mitra et al. (1976), Moore's (1903), and Murashige \& Skoog's medium (1962) devoid of sugar and plant growth regulators using sterile Pasteur pipettes and incubated at $25^{\circ} \mathrm{C} \pm 2^{\circ} \mathrm{C}$ under $12 \mathrm{hr}$ photoperiod $(1500$ lux). The $\mathrm{pH}$ of the media was adjusted to 5.8 before adding agar $0.5 \%(\mathrm{w} / \mathrm{v})$ and autoclaved at $121^{\circ} \mathrm{C}$ for $15 \mathrm{~min}$. Both liquid and agar nutrient media were used for spore germination and sporophyte formation. Gametophytes regenerated from spores were subcultured on different basal media (Knops, Knudson C, Mitra et al., Moore's and Murashige and Skoog's medium) for sporophyte formation. Germination percentage of the spores, growth area of the prothalli, and their development pattern were analyzed. Photomicrographs were taken with a labotriumph microscope. The culture tubes containing spore raised micropropagated plants of the two selected species were kept at room temperature $\left(30-32{ }^{\circ} \mathrm{C}\right)$ for a week before transplantation. For acclimatization, the plants with well developed roots $(5-8 \mathrm{~cm})$ were removed from culture tubes, washed in running tap water to remove the remnants of agar and each group was planted separately onto a $10 \mathrm{~cm}$ diameter polycup filled with different potting mixtures: river sand, garden soil 


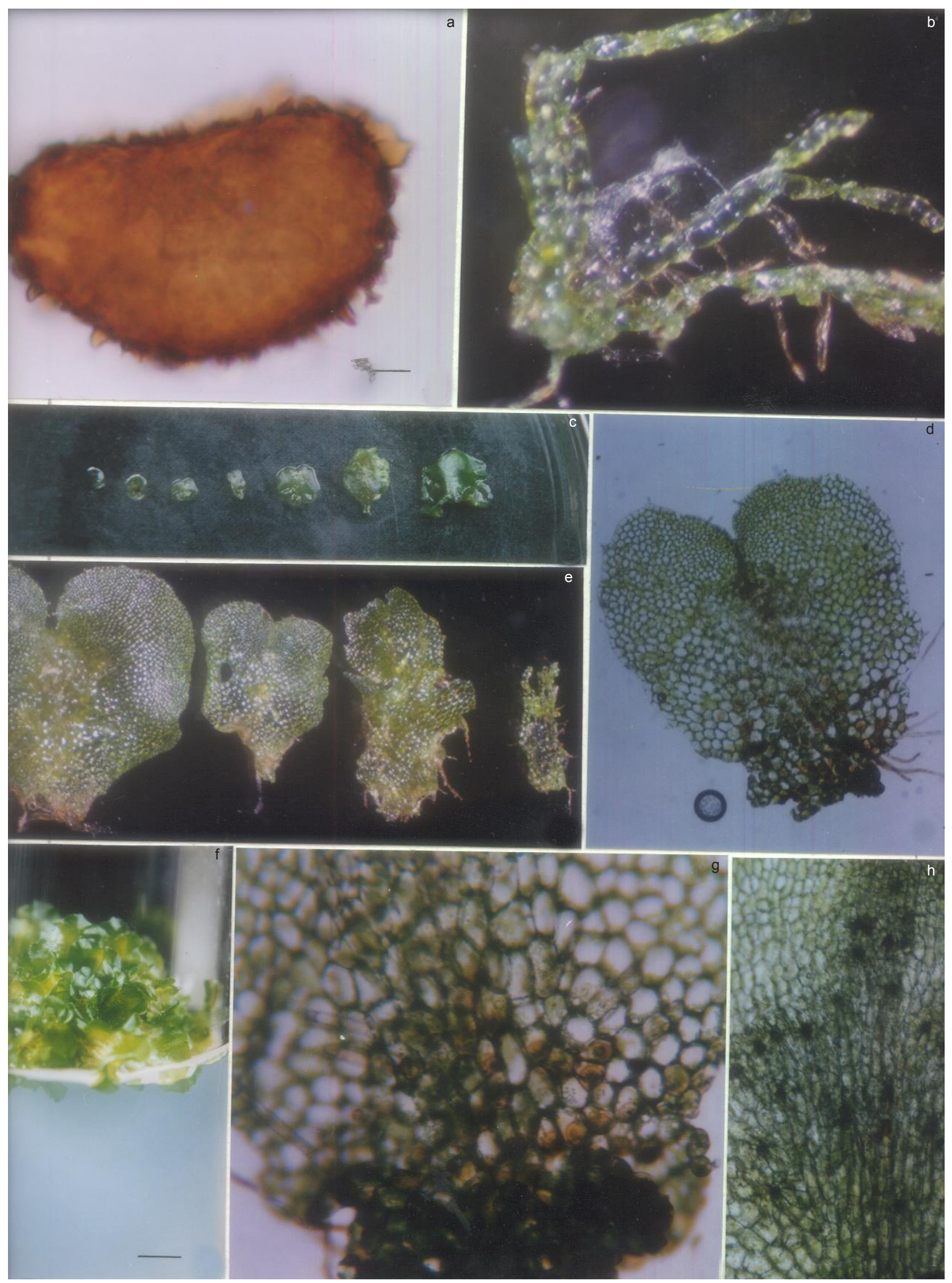

Image 1. In vitro spore culture: Different developmental stages of Pronephrium triphyllum

a - Spore $($ bar $1 \mathrm{~cm}=4 \mu \mathrm{m}) ; \mathrm{b}$ - Filamentous stage $($ bar $1 \mathrm{~cm}=250 \mu \mathrm{m}) ; \mathrm{c}$ - Different stages of prothalli - Camera view $(\mathrm{bar} 1 \mathrm{~cm}=$ $250 \mathrm{~mm}$ ); $\mathrm{d}$ - Cordate prothallus (bar $1 \mathrm{~cm}=250 \mathrm{~mm}$ ); e - Different stages of prothalli - microscopic view (bar $1 \mathrm{~cm}=400 \mu \mathrm{m})$;

$\mathrm{f}$ - Matured prothalli (bar $1 \mathrm{~cm}=4 \mathrm{~mm}) ; \mathrm{g}$ - Cordate prothallus with male sex organs (bar $1 \mathrm{~cm}=400 \mu \mathrm{m}) ; \mathrm{h}$ - Cordate prothallus with female sex organs (bar $1 \mathrm{~cm}=400 \mu \mathrm{m})$ 

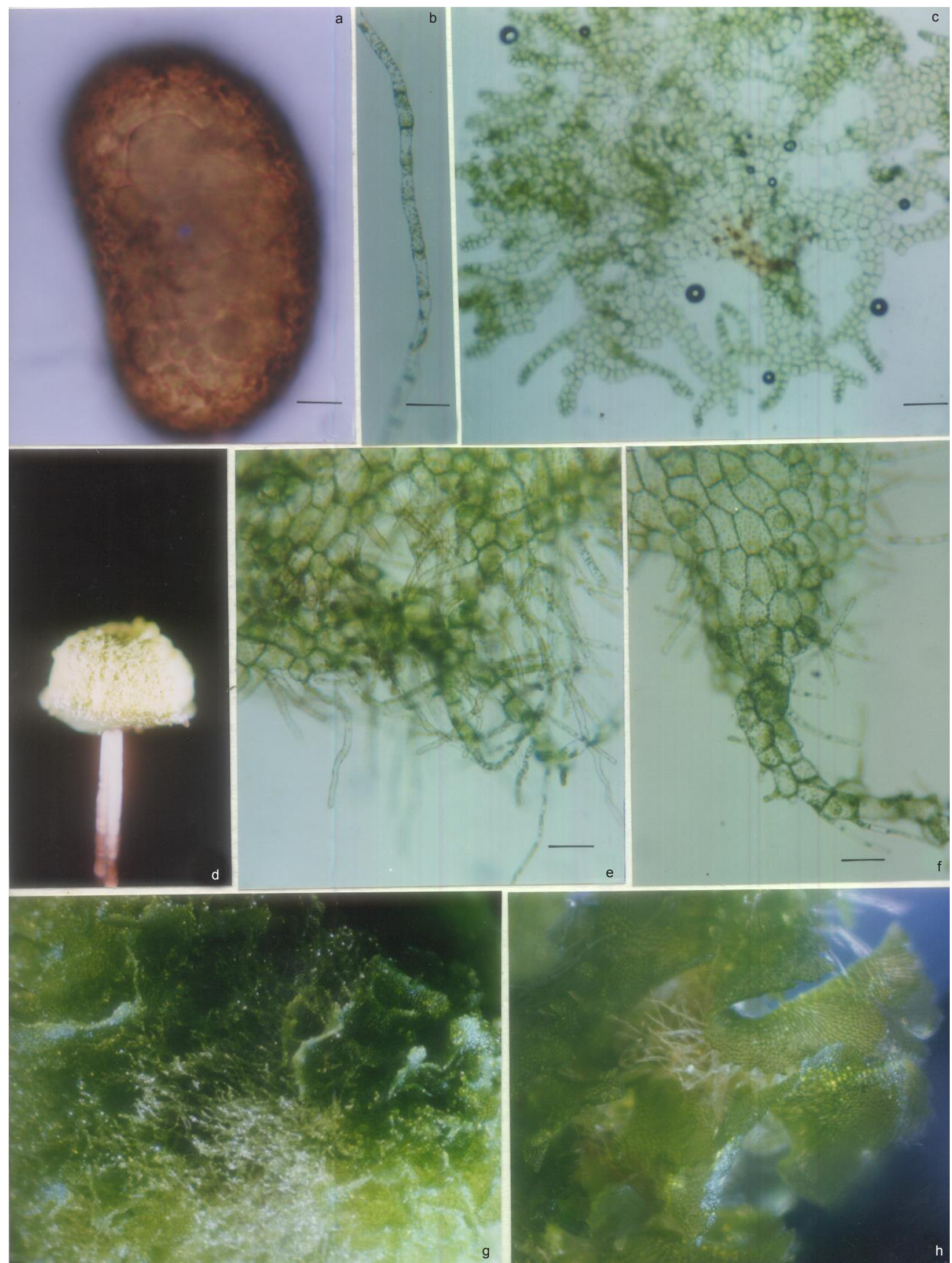

Image 2. In vitro spore culture: Different developmental stages of Spherostephanous unitus

a - Spore $($ bar $1 \mathrm{~cm}=4 \mu \mathrm{m}) ; \mathrm{b}$ - Filamentous stage $($ bar $1 \mathrm{~cm}=200 \mu \mathrm{m}) ; \mathrm{c}$ - Different stages of spore germination $(\mathrm{bar} 1 \mathrm{~cm}=200 \mu \mathrm{m})$ d - Gametophyte - filamentous stage; e - Gametophyte with rhizoids (bar $1 \mathrm{~cm}=250 \mu \mathrm{m}) ; \mathrm{f}$ - Origin of the prothalli (spore - prothalli) $($ bar $1 \mathrm{~cm}=250 \mu \mathrm{m}) ; \mathrm{g}$ - Surface view of gametophytes $($ bar $1 \mathrm{~cm}=600 \mu \mathrm{m}) . ; \mathrm{h}$ - Cordate prothalli with rhizoids $($ bar $1 \mathrm{~cm}=600 \mu \mathrm{m})$ 
and farm yard manures $(1: 1: 1)$ and sand and soil $(2: 1)$. The plants were kept in a mist chamber with a relative humidity of $70 \%$. Plants were irrigated at $8 \mathrm{hr}$ intervals for 3-4 weeks and establishment rate was recorded. The plantlets established in community pots were transferred to a shade net house for 3-4 weeks and then repotted in larger pots $(20 \mathrm{~cm}$ diameter) with one plant in each pot.

For cytological analysis, the in vitro raised young sporophytes (croziers) and immature sporangia in fertile fronds were squashed in acetocarmine after being fixed in a 1:3:6 mixture of glacial acetic acid, chloroform and $100 \%$ ethyl alcohol for 24 hours and then preserved in $95 \%$ ethyl alcohol. Mitotic and Meiotic chromosomes were observed in several cells for establishing the correct counts.

For Peroxidase analysis, the explants were ground well in a mortar and pestle with phosphate buffer $(\mathrm{pH}$ 7.0) under ice cool condition. The resultant slurry was centrifuged at $10,000 \mathrm{rpm}$ for $10 \mathrm{~min}$ at $4^{\circ} \mathrm{C}$ in a mikro 22R centrifuge and the supernatant was used as the enzyme source and stored in a $70^{\circ} \mathrm{C}$ deep freezer. Vertical discontinuous poly acrylamide gel electrophoresis (PAGE) was carried out for separation of isozyme. After the gel running, the gels were incubated in the dark with acetate buffer $(\mathrm{pH} 4.6)$ $85 \mathrm{ml}+$ Ethanol $(10 \mathrm{ml})$, O-Dianisidine $(100 \mathrm{mg})+$ $3 \% \mathrm{H}_{2} \mathrm{O}_{2}(1 \mathrm{ml})+4 \mathrm{ml}$ distilled water for $30 \mathrm{~min}$ for staining, 7\% acetic acid was used to stop the reaction and fixed the gel (Smila et al. 2007). The Isoperoxidase profiles were documented using the Vilber Loubermet Gel Documentation system and the similarity between the mother plants and in vitro spore derived plants were calculated using the Biogene software (Vilber Loubermet, Germany).

\section{RESULTS}

\section{Pronephrium triphyllum}

Spores collected from the mature fronds showed a variety of contamination and survival rates. On treatment with $0.1 \%(\mathrm{w} / \mathrm{v}) \mathrm{HgCl}_{2}$ for 5 min followed by washing with sterile distilled water for $15 \mathrm{~min}$ showed $75-80 \%$ of the spores free from the microbial contamination. The young spores showed a high percentage of mortality, even with a short duration of exposure to the sterilants. Spores were cultured in liquid and solid basal media (Knudson, Knop's, Mitra, Moore's and Murashige and Skoog's). Microbial contamination was more in the liquid media compared to the solid media. Spore germination time and germination percentages were dependent on the composition of the media. The spores sown on the Knop's basal agar medium showed the highest percentage $(38.3 \pm 1.13)$ of germination, followed in order, by the Moore's, Mitra and Knudson C media respectively $(22.3 \pm 0.81,21.3 \pm 0.83$ and $15.3 \pm 1.21)$. The time taken for spore germination also varied. In Knop's medium spores germinated after 38 days, while in other media they took a much longer time for germination. The pattern of germination is of Vittaria type. After 3-4 weeks, repeated longitudinal and transverse division of the anterior cells of protonema and expansion of the resultant daughter cells formed the prothallial plate. The prothallus was cordate type. The prothallus development was Drynaria type. Highest percentage of prothallus $(81.3 \pm 1.34)$ formation was observed in Mitra medium. The thallus was dioecious, dorsiventrally flattened which developed a midrib region with a cushion like structure and notched apical region.

The glandular hairs were present along the margin and the midrib regions. The sex organs and rhizoids originated from the midrib region. After 120 days, the male sex organs, antheridias were formed on the posterior end. After 160 days, the female sex organs, archegonias were formed on the anterior end (Images 1b-h). For sporophyte proliferation, the 180 day - old gametophytes were transferred to Knudson C, Knop's and Mitra liquid media. After 30 days, the sporophyte emerged from the midrib region on Knops liquid medium. After 15 days, the sporophytes were transferred to agar medium for sporophyte elongation. The highest percentage $(52.3 \pm 1.43)$ of sporophyte formation was observed in Knop's liquid medium compared to the other two media [Knudson C (16.5 \pm 1.31$)$ and Mitra (11.3 \pm 0.81$)]$ (Table 1). After 15 days of rooting, the in vitro derived plantlets were washed thoroughly in running tap water to remove the pieces of agar adhering to the roots and implanted in the pots containing a mixture of (1:2:1) sterile soil: sand: farmyard manure irrigated with $10 \mathrm{x}$ diluted Murashige and Skoog's / Knudson C liquid medium once a week. The pots were covered with poly bags to maintain the humidity. The plantlets were kept in a culture room 
Table 1. Effect of medium on spore germination, development of gametophyte and sporophyte and field establishment in Pronephrium triphyllum

\begin{tabular}{|c|c|c|c|c|c|c|c|}
\hline Medium \& pH & $\begin{array}{c}\% \text { of } \\
\text { Germination } \\
\pm \text { S.D. }\end{array}$ & $\begin{array}{c}\% \text { of Prothalli } \\
\text { formation } \pm \\
\text { S.D. }\end{array}$ & $\begin{array}{c}\% \text { of } \\
\text { Sporophyte } \\
\text { formation } \pm \\
\text { S.D. }\end{array}$ & $\begin{array}{c}\text { Mean no. } \\
\text { of croziers/ } \\
\text { prothallus } \pm \\
\text { S.D. }\end{array}$ & $\begin{array}{c}\text { Mean } \\
\text { length of } \\
\text { Sporophyte } \\
\pm \text { S.D. }\end{array}$ & $\begin{array}{c}\% \text { of } \\
\text { establishment } \\
\text { in polycups } \pm \\
\text { S.D. }\end{array}$ & $\begin{array}{c}\% \text { of } \\
\text { establishment } \\
\text { in Pots } \pm \text { S.D. }\end{array}$ \\
\hline KC Solid 5.8 & $15.3 \pm 1.27$ & $67.3 \pm 1.31$ & - & - & - & - & - \\
\hline KN Solid 5.8 & $38.3 \pm 1.13$ & $72.3 \pm 1.08$ & - & - & - & - & - \\
\hline Mi Solid 5.5 & $21.3 \pm 0.83$ & $81.3 \pm 1.31$ & - & - & - & - & - \\
\hline MO Solid 5.5 & $22.3 \pm 0.81$ & $68.4 \pm 1.34$ & - & - & - & - & - \\
\hline KC Liquid & - & - & $16.5 \pm 1.31$ & $1.78 \pm 0.34$ & $1.12 \pm 0.16$ & $73.5 \pm 1.24$ & $78.4 \pm 1.31$ \\
\hline KN Liquid & - & - & $52.3 \pm 1.43$ & $4.0 \pm 1.63$ & $1.38 \pm 0.74$ & $82.3 \pm 1.31$ & $79.3 \pm 1.31$ \\
\hline
\end{tabular}

Table 2. Effect of medium on spore germination, gametophyte, sporophyte formation and field establishment of Sphaerostephanos unitus

\begin{tabular}{|c|c|c|c|c|c|c|c|c|}
\hline Medium & $\begin{array}{l}\% \text { of } \\
\text { Germination } \\
\pm \text { S.D. }\end{array}$ & $\begin{array}{c}\% \text { of Prothalli } \\
\text { formation } \\
\pm \_ \text {S.D. }\end{array}$ & $\begin{array}{c}\% \text { of } \\
\text { Sporophyte } \\
\text { formation } \\
\text { 土_S.D. }\end{array}$ & $\begin{array}{c}\text { Mean no. } \\
\text { of croziers/ } \\
\text { prothallus } \pm \\
\text { S.D. }\end{array}$ & $\begin{array}{l}\text { Mean } \\
\text { length of } \\
\text { Sporophyte } \\
\pm \text { _S.D. }\end{array}$ & $\begin{array}{c}\% \text { of } \\
\text { establishment } \\
\text { in polycups } \pm \\
\text { S.D. }\end{array}$ & $\begin{array}{c}\% \text { of } \\
\text { establishment } \\
\text { in Pots } \pm \text { S.D. }\end{array}$ & $\begin{array}{c}\% \text { of } \\
\text { establishment } \\
\text { in field } \pm \text { S.D. }\end{array}$ \\
\hline KN Solid & $36.8 \pm 1.31$ & $73.8 \pm 1.31$ & $76.8 \pm 1.41$ & $3.2 \pm 1.13$ & $6.3 \pm 1.38$ & $79.8 \pm 1.34$ & $83.1 \pm 1.21$ & $74.8 \pm 1.31$ \\
\hline KC Solid & $26.3 \pm 1.30$ & $74.8 \pm 1.28$ & - & - & - & - & - & - \\
\hline MS Solid & - & - & - & - & - & - & - & - \\
\hline Mitra & $34.8 \pm 1.21$ & $66.3 \pm 1.21$ & - & - & - & - & - & - \\
\hline
\end{tabular}

for 15 days. After that, they were transferred to a green house (R.H. 80\%) under constant misting. After three weeks the plants were transferred to the field. The micropropagated plants showed $73.5 \pm 1.24 \%$ establishment during hardening and $72.3 \pm 1.24 \%$ establishment in the field at KBG. Subsequently the micropropagated plants were distributed to various botanic gardens for ex situ conservation. (Table 1) (Image 4c,d).

\section{Sphaerostephanos unitus}

Matured spores were used for culture initiation. The percentage of microbial contamination was less when the spores were treated with $0.1 \% \mathrm{HgCl}_{2}(\mathrm{w} / \mathrm{v})$ for $5 \mathrm{~min}$ and washed thoroughly using sterile distilled water for $15 \mathrm{~min}$. The survival of explants depended on the duration of the treatment with sterilants and the prolonged exposure (6-10 $\mathrm{min}$ ) to $0.1 \% \mathrm{HgCl}_{2}$ resulted in high percentage mortality. The spores were cultured in hormone free liquid and solid media (Knudson C, Knop's, Murahige \& Skoog's and Mitra). In the liquid media, the inoculated spores failed to germinate due to the high incidence of microbial contamination. After 35 days, the spores started to germinate in knops agar medium. The germination pattern was Vittaria type. The prothallial plate was formed after 30 days of culture, due to the repeated divisions of the cells. The prothallus development was Drynaria type. The thallus was dorsiventrally flat with an apical notch. The prothalli were cordate type. A high percentage of prothalli formation $(74.8 \pm 1.21)$ was observed in Knudson $\mathrm{C}$ medium. Glandular hairs were present on the margin and central areas of the gametophyte. The male and female sex organs formed on the midrib region. The male and female sex organs formed after 120 and 150 days respectively. The sporophyte emergence was noticed in the midrib regions after 180 days with the formation of sporophyte and root initials (Image $2 \mathrm{~b}-\mathrm{h})$. The highest percentage $(36.8 \pm 1.31)$ of spore germination was observed in the Knop's basal agar. Germination was not observed on the Murashige and Skoog's basal medium. The highest frequency of gametophyte formation and multiplication (74.8 11.28$)$ were observed in Knudson $\mathrm{C}$ basal medium. The sporophyte formation was observed only in Knop's medium, that too at a high $(76.8 \pm 1.41)$ percentage; there was no formation of sporophyte in other media (Table 2). Knop's medium also promoted the formation and 


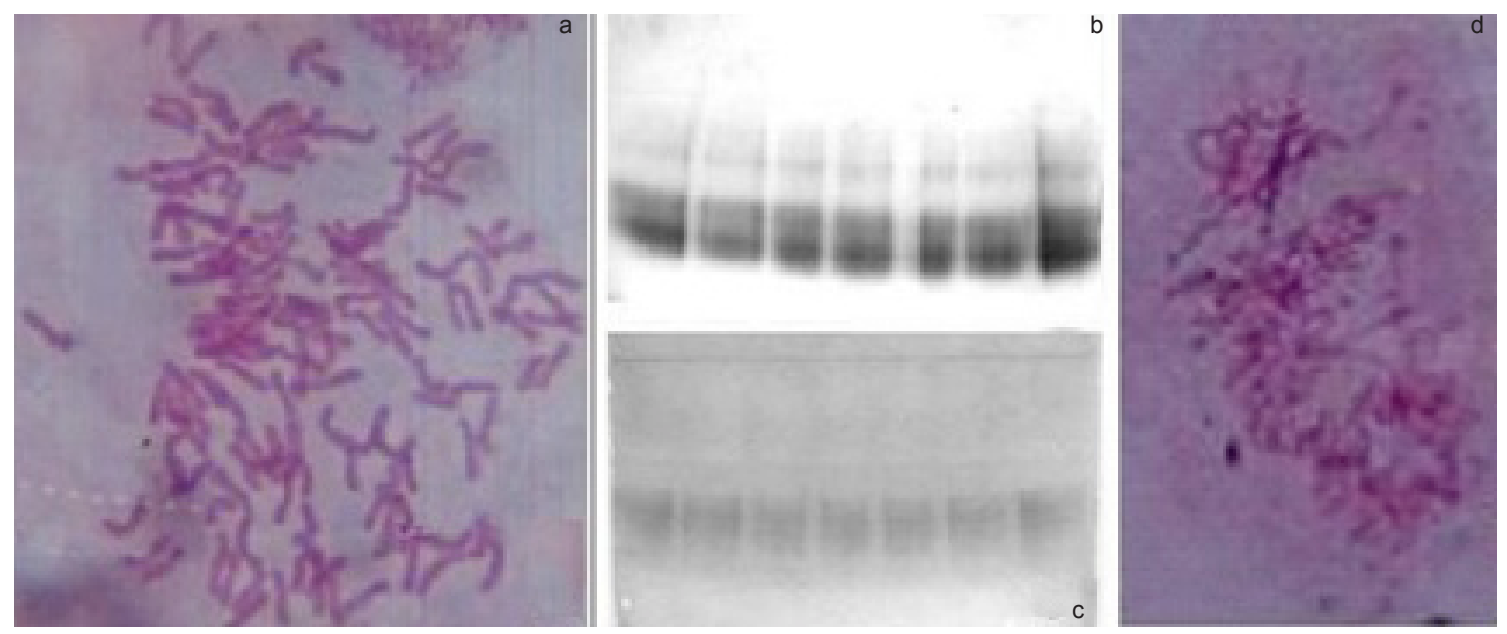

Image 3. Isoperoxidase profile and cytological studies on in vitro raised sporophytes and mother plants of $P$. triphyllum and S. unitus

a - P. triphyllum (Mitosis); b - P. triphyllum - Isoperoxidase Profile; c - S. unitus - Isoperoxidase d- Profile; S. unitus (Mitosis)

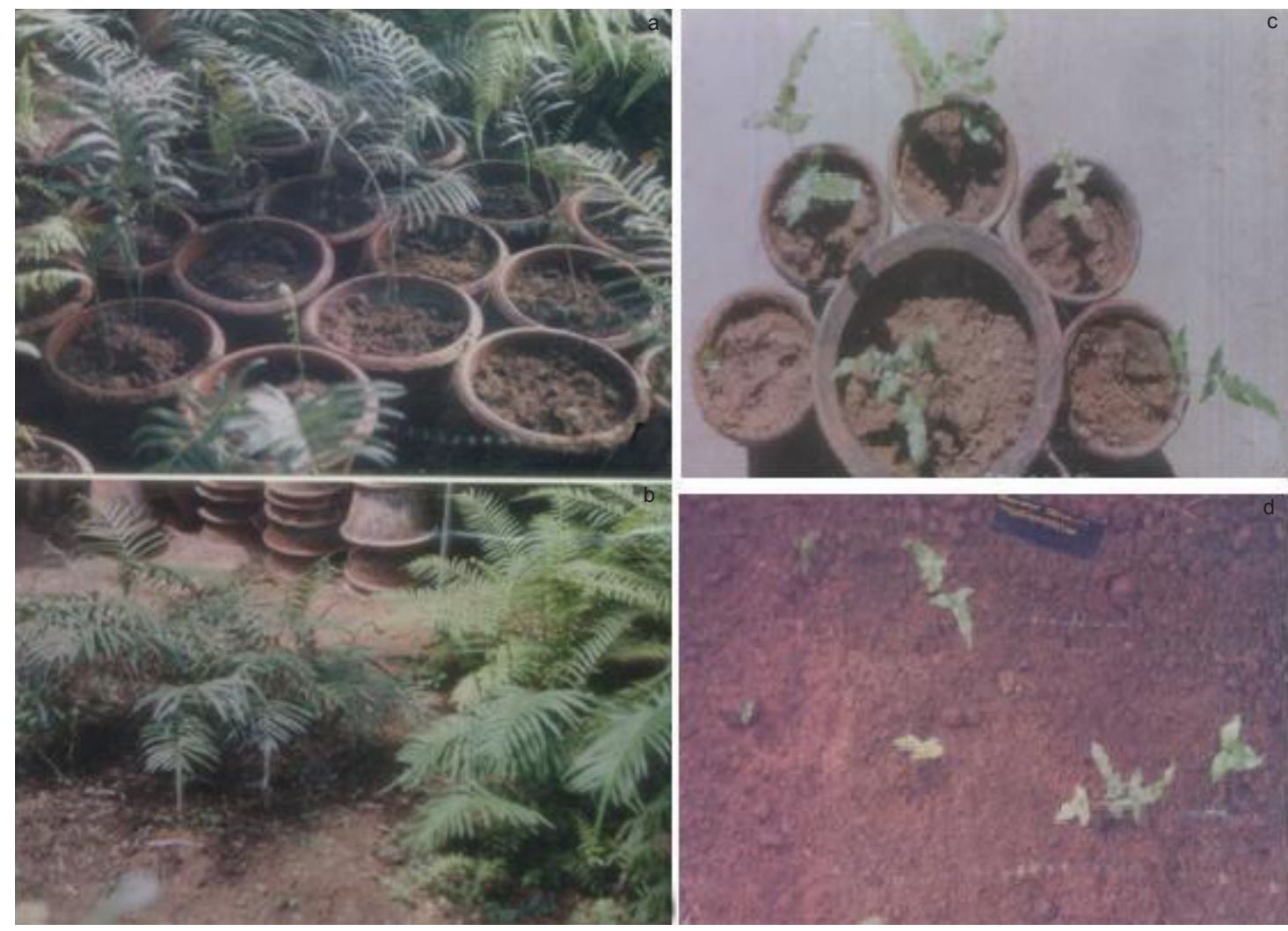

Image 4. Hardening and field establishment of in vitro raised plantlets of $P$. triphyllum, $S$. unitus a - S. unitus - hardened plants; b - Micropropagated \& hardened plants of S. unitus - reintroduced into KBG;

c - P. triphyllum - hardened plants; $\mathrm{d}$ - Micropropagated \& hardened plants of $P$. triphyllum - reintroduced into KBG

elongation of rhizoids. After 30 days of rooting, rooted plants were hardened in polycups containing a mixture (1:2:1) of sand: garden soil: farmyard manure, covered with unperforated poly bags and irrigated with $10 \mathrm{x}$ diluted MS liquid medium once a week. The plants were kept in the culture room for 15 days. Seventy eight percentage of the plants were successfully established in poly cups. After 15 days, the hardened plants were transferred to $15 \mathrm{~cm}$ diameter pots and kept in the green house. Eighty-five percentage of plants 
Table 3. Growth of micropropagated plants of P. triphyllum and S. unitus re-established into Kodaikannal Botanic Garden at Kodaikanal, Tamil Nadu, India

\begin{tabular}{|c|c|c|c|c|c|c|}
\hline Plant species & $\begin{array}{c}\text { No. of plants } \\
\text { transferred to } \\
\text { polycups }\end{array}$ & $\begin{array}{c}\text { \% of } \\
\text { establishing in } \\
\text { polycup }\end{array}$ & $\begin{array}{c}\text { No. of plants } \\
\text { transferred to } \\
\text { pots }\end{array}$ & $\begin{array}{c}\text { \% of } \\
\text { establishment } \\
\text { in pots }\end{array}$ & $\begin{array}{c}\text { No. of plants } \\
\text { transferred to } \\
\text { field }\end{array}$ & $\begin{array}{c}\text { \% of } \\
\text { establishment }\end{array}$ \\
\hline P. triphyllum & 375 & 73.5 & 275 & 77 & 120 & 85 \\
\hline S. unitus & 300 & 79 & 235 & 73 & 120 & 75 \\
\hline
\end{tabular}

were well established in the green house. After six months, the plants, $34 \mathrm{~cm}$ in height, having 10 to 12 croziers were repotted, for distribution to various Botanic Gardens, such as the Calicut University Botanic Garden, Kozhikode; TBGRI, Trivandrum; Gurukula Botanic Garden, Wyanad and Genepool Garden, Gudalur for ex situ conservation. Many plants were also transferred to their natural settings in the Kodaikanal Botanic Garden, Kodaikanal for field establishment (Table 3) (Images 4a-d).

Isoperoxidase analysis revealed the genetic uniformity between the mother plants and in vitro spore raised sporophytes. The MW - Rf values and banding positions confirmed $100 \%$ genetic uniformity. In addition they provided the biochemical marker for the two selected species. P. triphyllum (Image 3b) showed three different bands in three different active regions (0.510, 0.664 and 0.764). S. unitus (Image 3c) showed only two bands in two different active regions $(0.478$ and 0.536). Cytological studies on root tips of ten randomly selected plants established in KBG revealed the presence of 144 chromosomes in P. triphyllum (Image 3a) and 72 chromosomes in S. unitus (Image 3d) confirming the mother plants chromosomes.

\section{DISCUSSIONS}

Spores are tiny objects which are used liberally by ferns for reproduction. A spore contains only half the normal chromosome number and no embryo. The single celled spores are excellent experimental material on par with pollen grains and isolated cells of higher plant species. Observations over the past twenty years reveal that spores are produced in huge numbers by nature, but the percentage of spore germination and their developmental physiology rate is very poor due to unfavourable conditions. Each and every species requires their unique environment for their growth and development; most of the rare and endangered ferns failed to obtain the optimal growth condition for their development. The present study also confirmed the previous observations. However, there are a few published reports on successful germination of spores in vivo (Theuerkauf 1994). Under natural conditions, the percentage of spore germination is low due to the prevalence of unfavourable factors, both biotic and abiotic. It is not unusual that the spores are dispersed by wind to places unfavourable for their germination. The spores otherwise having little stored food materials, seldom germinate in the wild. The spores can germinate under in vitro conditions easily. The in vitro spore culture methods have advantages over soil based conventional methods. The in vitro culture techniques have been used to study different aspects of spore germination, growth and development of gametophytes and sporophytes in ferns (Nester \& Coolbaugh 1986; Hickok et al. 1987; Miller \& Wagner 1987; Melan \& Whittier 1990). However there are number of factors such as temperature, humidity, light, and nutrient compositions (Raghavan 1989) which need to be addressed for successful in vitro spore culture. Tissue culture which tends to be more sophisticated than spore culture is also advocated and successfully explored for horticulture propagation of selected ferns (Hennen \& Sheehan 1978; Padhya \& Mehta 1981; Higuchi et al. 1986). Successful culture initiation, be it spore culture or tissue culture, depends on a number of physical and chemical factors. A number of workers have studied spore germination under the influence of various physiological and chemical parameters (Mehra \& Palta 1971; Sharma \& Vangani 1988; Sharma \& Sharma 1991). In the present investigation also, the spores of all the selected species were cultured under varied conditions with the object of developing viable protocols for mass multiplication and conservation. In a comparative perspective, spore cultures are more desirable for rare species conservation than tissue culture as it retains the genetic variability inherent in the genetic make up of a species. Nowadays, accurate 
recordings of the genetic uniformity and chemical characterization of the plants are needed to be verified before conservation. Analysis of isoenzyme banding profile is considered to be one of the best and cheapest system for the analysis of population structure, genetic uniformity and developmental pattern, due to its role in the metabolic pathway. It functions in harmony with other enzymes within the organizational framework of cells and Isoenzyme often exhibits tissue or cell specificity (Zeidler 2000). These banding profiles are useful in differentiating the selected species and the induced variants. In the present study also, Isoperoxidase studies revealed the biochemical uniformity between the mother plants and the in vitro spore raised plants. The earlier reports are directly consonant with the present study and strengthen the role of isoperoxidase in the study of genetic uniformity (Nair 2000; Johnson 2003; Nikhat 2004; Sonali 2004). Since the 1960s, Electrophoresis coupled with isoenzyme has been the tool of choice for studies of heritable variation by geneticist, systematist and population biologist (Zeidler 2000). The isoperoxidase profiles will be used as a taxonomic tool for the characterization of the two important ferns in the future. The present study completely demonstrated the life cycle and reproductive biology of the two rare and endangered ferns of the Western Ghats, India. The established protocol of the present study will be useful for the multiplication and conservation of the two threatened ferns of the Western Ghats. The same protocol may also be applied to similarly threatened conserved ferns.

\section{REFERENCE}

Fay, M.F. (1994). In what situations is in vitro culture appropriate to plant conservation? Biodiversity and Conservation 3: 176-183.

Hennen, G.R. \& T.J. Sheehan (1978). In vitro propagation of Platycerium stemaria (Beauvois) Desv. Hortscience 13: 245.

Hickok, L.G., T.R. Warne \& M.K. Slocum (1987). Ceratopteris richardii: Applications for experimental plant biology. American Journal of Botany 59: 458-465.

Higuchi, H., W. Amaki \& S. Suzuki (1986). In vitro propagation of Nephrolepis cordifolia (L.) Presl. Scientia Horticulturae 32: 105-113.

Irudayaraj, V., V.S. Manickam \& M. Johnson (2003). Incidence of Apospory in Pteris confusa T. G. Walker.
Phytomorphology 53(1): 73-77.

Johnson, M. (2003). In vitro studies on some rare and endangered ferns of Western Ghats, south India. PhD Thesis. Manonmanium Sundarnar University, Tamil Nadu, India.

Johnson, M., V.S. Manickam \& V. Irudayaraj (2005). In vitro studies on the agamsporous fern (Pteris gongalensis T. G. Walker). Ethiopian Journal of Science and Technology 3(1): $1-8$.

Johnson, M. \& V.S. Manickam (2006). Adventitious Proliferation of secondary and tertiary prothalli from the primary prothalli of Pronephrium articulatum (Houlst. \& Moore) Holt. Ethiopian Journal of Science and Technology 3(2): 93-96.

Johnson, M. \& V.S. Manickam (2006). In vitro studies on normal and abnormal life cycle of Metathelypteris flaccida (B1.) Ching. Ethiopian Journal of Science and Technology 4(1): 37-44.

Johnson, M., V.S. Manickam, A. Benniamin \& V. Irudayaraj (2008). Conservation of endangered ferns of Western Ghats through micropropagation, pp. 183-191. In: Verma, S.C., S.P. Khuller \& H.K. Cheema (eds.). Perspective in Pteridophytes. Bishen Singh Mahendra Pal Singh, Dahradun, India.

Kaur, S. (1989). Economic exploitation and conservation emerging areas in the study. Indian Fern Journal 6: 23-29.

Knops, N. (1885). Quantitative Untersuchungan uber die Ernahrungsprozesse der pflangen Land wirtsch Vers, stn. 7: 93-107.

Knudson, L. (1946). A nutrient solution for the germination of orchid seed. Bulletin of American Orchid Society 15: 214 217.

Luo, G.H. (1988). Medicinal pteridophytes in China. pp. 309312. In Singh, K.H. \& K.C. Kramer (eds.). Proceedings of the International symposium on systematic pteridology China Science and Technology Press, Beijing China.

Manickam, V.S. (1995). Rare and endangered ferns of the Western Ghats of South India. Fern Gazette 15: 1-10.

Manickam, V.S. \& V. Irudayaraj (1992). Pteridophyte flora of the Western Ghats - south India, B.I. Publications New Delhi, India.

Manickam, V.S., S. Vallinayagam \& M. Johnson. (2003). Micropropagation and Conservation of rare and endangered ferns of Western Ghats through in vitro culture. pp: 497504. In: Chandra, S. \& M. Srivastava (eds.). Pteridology in the New Millennium. Kluwer Academic Publishers, Netherlands.

Medina, R., M. Faloci, M.A. Marassi \& L.A. Mroginski (2004). Genetic stability in rice micropropagation. Biocell 28(1): 13-20.

Mehra, P.N. \& H.K. Palta (1971). In vitro controlled differentiation of the root callus of Cyclosorus dentatus. Phytomorphology 21: 367-375.

Melan, M.A. \& D.P. Whittier (1990). Effects of in organic nitrogen sources in spore germination and gametophyte growth in Botrychium dissectum. Plant cell and environment 13: 477-482.

Miller, J.H. \& M.P. Wagner (1987). Co-requirement for 
Calcium and Potassium in the germination of spores of the fern Onoclea sensibilis. American Journal of Botany 74: 1585-1589.

Mitra, G.C., R. N. Prasad. \& R. Chowdhury (1976). An inorganic salts and differentiation of protocornes, in seed callus of an orchid and correlated changes in free amino acids content. Indian Journal of Experimental Biology 14: 350-351.

Moore, G.T. (1903). Methods of growing pure cultures of algae. Journal of Applied Microscopy 6: 2309-2314.

Murashige, T. \& F. Skoog. (1962). A revised medium for rapid growth and bioassay with tobacco tissue culture. Physiologia Plantarum 15: 473-497.

Nair, L.G. (2000). Conservation through micropropagation restoration of selected woody medicinal plants. PhD Thesis. Kerala University, Thiruvananthapuram, Kerala, India

Nester, J.F. \& R.C. Coolbaugh (1986). Factors influencing spore germination and early gametophyte development in Anemia mexicanum and Anemia phyllitidis. Plant physiology 82: 230-235.

Nikhat, Y. (2004). In vitro multiplication and electrophoretic studies on Passiflora mollissima H.B. K. Bailey. MPhil Thesis. Periyar University, India.

Padhya, M.A. \& A. R. Mehta. (1981). Propagations of fern (Nephrolepis) through tissue culture. Plant cell Reports. 1: 261-263.

Raghavan, V. (1989). Developmental biology of fern gametophytes. Cambridge University press Cambridge, 27-53pp.

Raven, P.H. (1999). World's biodiversity becoming extinct at levels rivaling earth's past "mass extinctions". Botanic Garden Conservation News 3: 31-32.

Sabu, K.K., P. Padmesh \& S. Seeni (2001). Estimation of active principle content and isozymes of Andrographis paniculata Nees (Kalmegh): An important medicinal plant of India. Journal of Medicinal Aromatic Plant Science 23: 637-647.

Sara, S.C. (2001). Conservation of selected rare and endangered ferns of the Western Ghats through micropropagation and restoration. $\mathrm{PhD}$ Thesis. Manonmaniam Sundaranar University, Tirunelveli, India.

Sara, C.S. \& V.S. Manickam (2005). In vitro propagation of the critically endangered fern Cyathea crinita (Hook.) Copel. Asian Journal of the Microbiology Biotechnology Environmental Science 7: 527-536.

Sara, C.S. \& V.S. Manickam (2007). In vitro developmental ontogeny and life cycle of a are fern species - Thelypteris confluens (Thunb.) Morton. Indian Journal of Biotechnology 6: 372-380.

Sara, S.C., V.S. Manickam \& R. Antonisamy (1998). Regeneration in kinetin treated gametophytes of Nephrolepis multiflora (Roxb.) Jarret in Morton. Current Science 75: 503-508.

Sharma, A. \& B.D. Sharma. (1991). Hitherto unreported methods for the multiplication of ferns. Phytomorphology 41: 271-274.

Sharma, B.D. \& P. Vangani (1988). Effects of gibberllin (GA3) on development and sex expression in the gametophytes of Cheilanthes farinos (Forssk.) Klf. Indian Fern Journal 5: 1-4.

Smila, H., M. Johnson \& M. Rajasekarapandian (2007). Studies on varietal difference, tissue specificity and developmental variation of esterase and peroxidase isozymes in pearl millet (Pennisetum glacum (L.) R. Br.). Indian Journal of Biotechnology 6: 91-99.

Sonali, D. (2004). Micropropagation and Intra specific variation studies on Vitex negundo L. MPhil Thesis, Periyar University, India.

Theuerkauf, W.D. (1994). Preserving southern Indian pteridophytes. Botanic Garden Conservation News 2: 54-55.

Vallinayagam, S. (2003). Micropropagation of rare and endangered ferns of Western Ghats. PhD Thesis.Manonmaniam Sundaranar University, Tirunelveli, India.

Zeidler, M. (2000). Electrophoretic analysis of plant isozymes. Acta Universitatis Palackianae Olomucensis, Facultas Rerum Naturalium Biology 38: 7-16.
Author Details: DR. M. JoHnson standardized the large scale multiplication protocol for thirteen rare and endangered ferns of the Western Ghats under the Ministry of Environment and Forest, New Delhi sponsored project. He has also published about 66 papers in national and international journals on large scale propagation, phytochemical, antimicrobial activity and isozymic profile of Indian medicinally important plants.

ReV. Dr. V.S. MANICKAM carried out several projects sponsored by DST, DBT, Moen, UGC. During the last twenty five years he has surveyed Pteridophytes of the Western Ghats and Angiosperms of Tirunelveli Hills. He coordinated the All India Coordinated Project on Taxonomy for Pteridophytes and Gymnosperms. He has completed several projects on ex situ conservation of several rare and endangered ferns and angiopserms. He has published six books and more than 300 research papers. 